\title{
GEOTECHNICAL AND MICROSTRUCTURAL PROPERTIES OF CEMENT-TREATED LATERITES STABILIZED WITH RICE HUSK ASH AND BAMBOO LEAF ASH
}

\author{
Emeka Segun Nnochiri ${ }^{a, *}$, Olumide Moses OGundipe $^{b}$, \\ SAMUel Akinlabi Ola ${ }^{a}$
}

\author{
${ }^{a}$ Afe Babalola University, Ado-Ekiti, College of Engineering, Department of Civil and Environmental \\ Engineering, PMB 5454, Ado-Ekiti, Nigeria \\ ${ }^{b}$ Ekiti State University, Ado-Ekiti, College of Engineering, Department of Civil Engineering, PMB 5353, \\ Ado-Ekiti, Nigeria \\ * corresponding author: segunemeka@yahoo.com
}

\begin{abstract}
This study investigated the geotechnical and microstructural properties of cement-treated laterites stabilized with rice husk ash and bamboo leaf ash. In going about the tests, the soil sample was subjected to compaction, California Bearing Ratio (CBR) and preliminary tests; such as specific gravity, particle size distribution and Atterbergs limits to determine its index properties. Thereafter, the soil sample was mixed with cement at varying proportions of $0-12 \%$ at $2 \%$ intervals and also, separately mixed with bamboo leaf ash (BLA) and rice husk ash (RHA) in proportions of $0-16 \%$ at $2 \%$ intervals. The mixes at each stage were subjected to compaction, Atterberg limits and CBR tests. The highest values were $66.7 \%$ and $54.8 \%$ for unsoaked and soaked CBR at $6 \%$ cement $+8 \%$ BLA and $78.5 \%$ and $63.8 \%$ for unsoaked and soaked CBR at $8 \%$ cement $+8 \%$ RHA. Samples at these optimal CBR values were subjected into Scanning Electron Microscopy (SEM) and X-Ray Diffraction (XRD) tests. Results showed that new compounds were formed and there were changes in the microstructural arrangements. It can therefore be concluded that pozzolanic and cement hydration reactions actually took place in the course of stabilization.
\end{abstract}

Keywords: Bamboo leaf ash, laterite soil, ordinary Portland cement, rice husk ash, soil stabilization.

\section{INTRODUCTION}

According to Bello et al. [1, soil stabilization is the treatment of soils to enable their strength and durability to be improved upon in such a way that they become adequately suitable for construction beyond their original capability. Common industrial stabilizers are cement, lime, flyash and bitumen. Furthermore, the high cost of cement, which is generally used as binder, has led to the search for natural materials as either alternative or complement. Studies on alternatives or complements to cement has so far centered on the partial replacement of cement with different materials [2]. Recent innovations in stabilization include using microbially induced calcite precipitation technique, alkali activated flyash [3-7]. The need for improvement in the strength and durability of lateritic soil in recent times cannot be overemphasized, this has motivated researchers towards using stabilizing materials that can be sourced locally at a very low cost [1]. These local materials can be categorised as either agricultural or industrial wastes [8]. Numerous researchers have come up to establish the pozzolanic capability of many agro-wastes, such as bagasse ash, sawdust ash, corn cob ash, guinea corn husk ash, banana leaf ash, palm kernel shell ash, ground nut shell ash, cassava peel ash, walnut shell ash, ground nut husk ash, cattle bone ash, oil palm frond ash to mention but a few [1, 9, 20. The use of industrial and agricultural waste products in the construction of roads has been the essence of research for economic and environmental reasons 21. In line with the Federal Government's drive for Nigeria to be self-sufficient in rice production and to save hundreds of billions of naira annually on rice importation, local rice production has reached 15 million metric tonnes [22], this, in turn has resulted to increased generation of rice husk as waste. Pozzolanic reactions take place when significant amounts of reactive $\mathrm{CaO}, \mathrm{Al}_{2} \mathrm{O}_{3}$ and $\mathrm{SiO}_{2}$ are mixed in presence of water. Usually $\mathrm{CaO}$ is added as lime or cement, meanwhile $\mathrm{Al}_{2} \mathrm{O}_{3}$ and $\mathrm{SiO}_{2}$ can be present in the material to develop cementation gels to be added as cement or, for example, with a pozzolan. It is in this process that the hydration of the $\mathrm{CaO}$ liberates $\mathrm{OH}^{-}$ions, which causes an increase $\mathrm{pH}$ values up to approximate 12.4. Under these conditions pozzolanic reactions occur: the $\mathrm{Si}$ and $\mathrm{Al}$ combine with the available $\mathrm{Ca}$, resulting in cementitious compounds called Calcium Silicate Hydrates (CSH) and Calcium Aluminate Hydrates (CAH) [23, 24]. This study therefore investigates the microstructural changes of cement-treated soil stabilized with rice husk ash and bamboo leaf ash due to pozolanic reactions. 


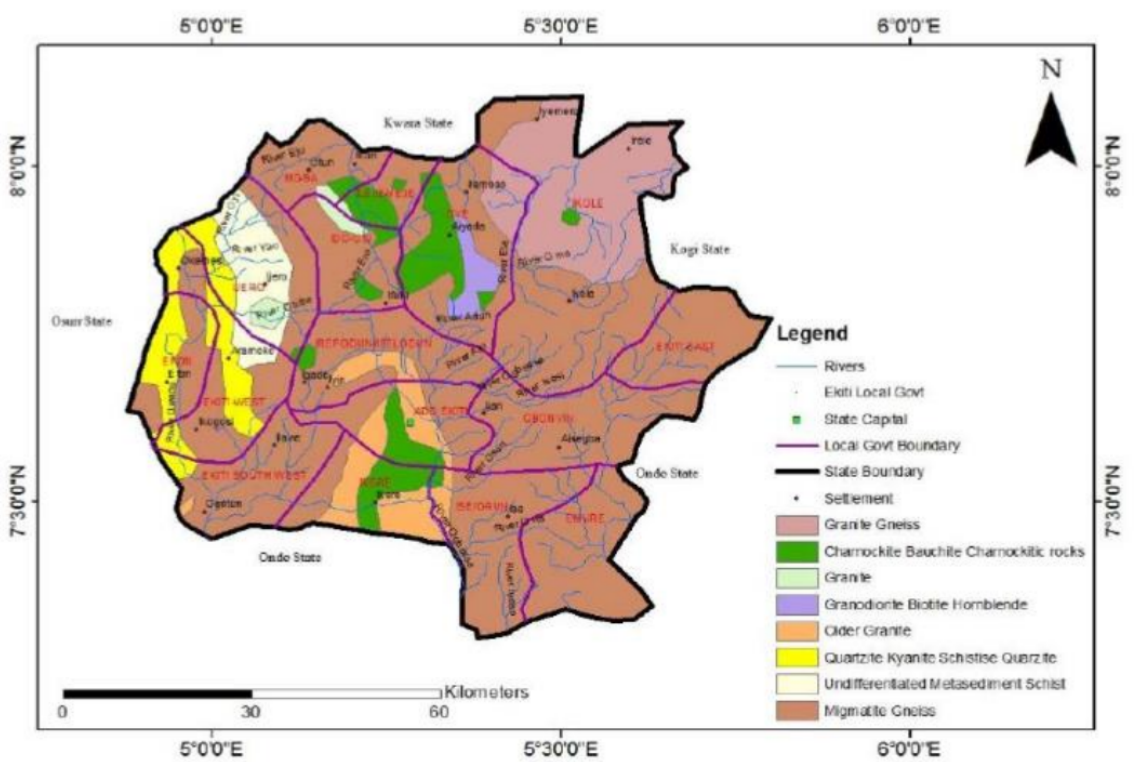

Figure 1. Geological Map of Ekiti State [25].

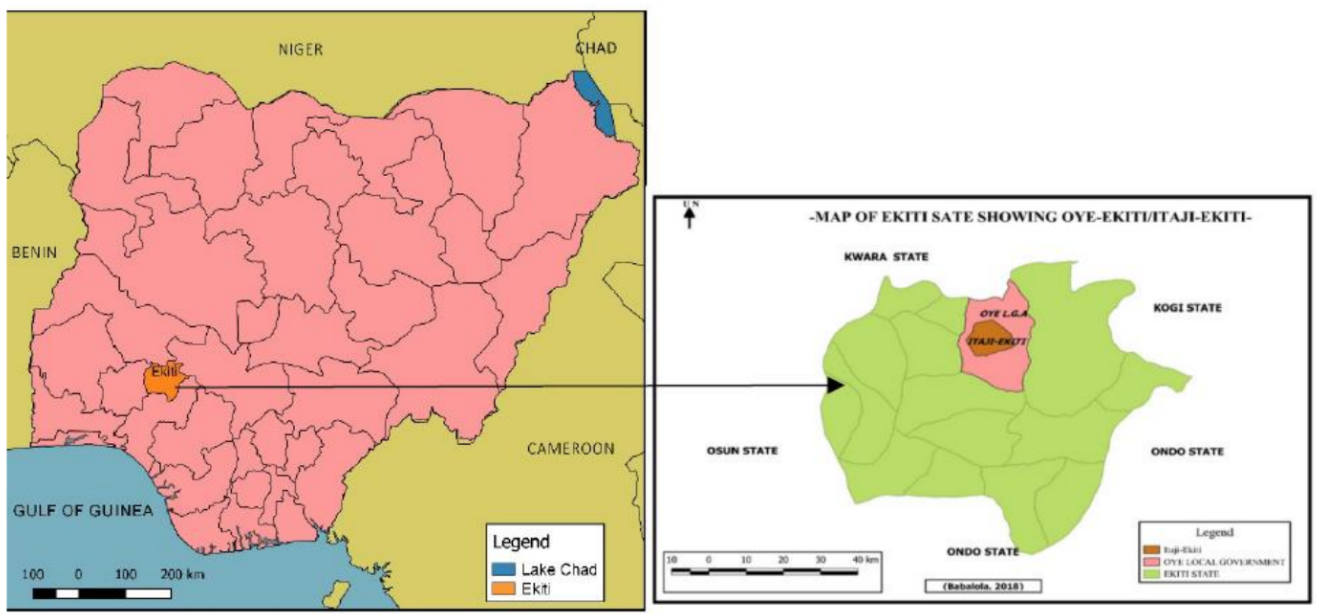

Figure 2. Map of Nigeria, showing Oye Ekiti Local Government Area [26].

\section{GeOlOGy OF STUDY AREA}

Oye-Ekiti has its geographical coordinates as $7^{\circ} 48^{\prime} 0^{\prime \prime}$ North, $5^{\circ} 20^{\prime} 0$ " East. Ekiti state as a whole is underlain by the Precambrian rocks of the Basement Complex of Southwestern Nigeria which covers about $50 \%$ of the land surface of Nigeria. The major lithological units include the granite gneiss, migmatites gneiss and charnockite. The Basement rocks show great variations in grain size and in mineral composition. The rocks are predominantly quartz, gneisses and schists consisting essentially of quartz with small amounts of white micaceous minerals. In grain size and structure, they vary from very coarse grained pegmatite to medium grained gneisses [25]. Figure 1 shows the geological map of Ekiti state, while Figure 2, shows the map of Oye in Ekiti State as a part of Nigeria.

\section{MAterials AND Methods}

\subsection{Materials}

The materials used were: rice husk ash, bamboo leaf ash, soil sample, ordinary Portland cement and water.

Bamboo Leaf Ash (BLA): Fresh bamboo leaves were collected and sun-dried. The dried bamboo leaves were thereafter burnt in an open air and then heated in furnace at $600{ }^{\circ} \mathrm{C}$ for 2 hours. Before usage, the obtained BLA ash was sieved through BS sieve No. $200(75 \mu \mathrm{m}$ or $0.075 \mathrm{~mm})$. Its properties met the minimum standards of cement as required by BS 12 [27].

Rice Husk Ash (RHA): The rice husk ash was burnt in open atmosphere and the black ashes obtained were heated in a muffle furnace for 3 hours at $650{ }^{\circ} \mathrm{C}$ to $800^{\circ} \mathrm{C}$ to obtain a white coloured ash, this is to enable the transformation of the silica content into amorphous phase which can react with 


\begin{tabular}{lcccc}
\hline Elemental Oxide & Soil sample (\%) & BLA (\%) & RHA (\%) & Cement (\%) \\
\hline $\mathrm{SiO}_{2}$ & 54.1 & 72.75 & 76.00 & 21.60 \\
$\mathrm{Al}_{2} \mathrm{O}_{3}$ & 42.10 & 5.90 & 2.68 & 5.90 \\
$\mathrm{Fe}_{2} \mathrm{O}_{3}$ & 0.011 & 1.85 & 3.90 & 2.70 \\
$\mathrm{CaO}$ & 0.004 & 4.45 & 3.00 & 63.32 \\
$\mathrm{MgO}$ & 0.22 & 2.05 & 1.68 & 1.61 \\
$\mathrm{TiO}_{2}$ & 2.10 & - & - & - \\
$\mathrm{MnO}$ & 1.365 & - & - & - \\
$\mathrm{K}_{2} \mathrm{O}$ & 0.10 & - & - & - \\
$\mathrm{SO}_{3}$ & - & - & - & 3.7 \\
$\mathrm{LOI}$ & - & 13.0 & 12.74 & 1.17 \\
\hline $\mathrm{Total}$ & $100 \%$ & $100 \%$ & $100 \%$ & $100 \%$ \\
\hline
\end{tabular}

TABle 1. Chemical composition of soil sample, BLA, RHA and cement.

the $\mathrm{CaOH}$ liberated during the hardening of cement to further form cementatious compounds.

Soil Sample: The soil sample was collected from an existing burrow pit in Oye-Ekiti, Nigeria, at a depth not less than $1.2 \mathrm{~m}$ below the ground level at 5 different points of about $3 \mathrm{~m}$ apart using the disturbed sampling technique. It was brought to the soil laboratory and marked indicating the soil description, sampling depth and date of sampling. The soil sample was air-dried for two weeks to allow for partial elimination of natural water content which may influence the analysis, then sieved with sieve No. 4 ( $4.75 \mathrm{~mm}$ opening) to get the final soil sample for the tests. After the drying period of two weeks, lumps in the sample were pulverized, using a pestle and mortar under minimal pressure.

Ordinary Portland Cement: This was obtained from a cement store.

Water: The water used was obtained from the running taps in the laboratory, the source was borehole. Distilled water was not used so as to obtain results that would reflect in-situ conditions.

\subsection{Methods}

The chemical compositions of the bamboo leaf ash, rice husk ash, cement and soil sample respectively were determined by means of gravimetric method.

The soil sample was subjected to preliminary tests, such as the particle size distribution (wet sieving), specific gravity and Atterberg limits. The natural soil sample was also subjected to compaction tests and the California bearing ratio (CBR). The soil sample was later separately treated with cement at values of $0,2,4,6,8,10$ and $12 \%$ which were separately mixed with rice husk ash (RHA) and bamboo leaf ash (BLA) at varying proportions of $2,4,6,8,10,12$, 14 and $16 \%$. These samples were each subjected to Atterberg limits, compaction and California bearing ratio. The CBR was however modified in conformity with the recommendation of the Nigerian General
Specification 28, which stipulates that specimens be cured for six days unsoaked, immersed in water for 24 hours and allowed to drain for 15 minutes before testing.

The entire tests were carried out according to BS 1377 [29] for natural soil sample and British Standard 1924 [30] for stabilized samples. Natural and stabilized soil samples at optimum amounts of additives were thereafter subjected to scanning electron microscopy (SEM) and X-ray diffraction (XRD).

\section{Results And Discussions}

Table 1 shows the chemical composition of the soil sample, RHA, BLA and the ordinary Portland cement by percentage weight composition. According to Ola 31, if silica $\left(\mathrm{SiO}_{2}\right)$ to sesquioxide $\left(\mathrm{Fe}_{2} \mathrm{O}_{3}+\right.$ $\mathrm{Al}_{2} \mathrm{O}_{3}$ ) ratio of a given soil sample is less than 1.33, the soil sample can be said to laterites, if it is between 1.33 and 2.0, it can be said to be lateritic soil, and if it is above 2.0, it is non-lateritic soil. The silica to sesquioxide ratio of the soil sample is 1.28 . It therefore means that the soil sample is laterite soil.

Furthermore, both BLA and RHA pass for pozzolanic materials. According to ASTM C618 [32, a material can pass for a pozzolan if the sum by addition of weight percentages of $\mathrm{Fe}_{2} \mathrm{O}_{3}, \mathrm{Al}_{2} \mathrm{O}_{3}$ and $\mathrm{SiO}_{2}$ equal at least $70 \%$. Table 1, under RHA, the sum of $\mathrm{SiO}_{2}, \mathrm{Al}_{2} \mathrm{O}_{3}$ and $\mathrm{Fe}_{2} \mathrm{O}_{3}$, equals 86.88. This additive (RHA) is a pozzolan. Also, for BLA, the sum of $\mathrm{SiO}_{2}, \mathrm{Al}_{2} \mathrm{O}_{3}$ and $\mathrm{Fe}_{2} \mathrm{O}_{3}$, equals $80.55 \%$, therefore, these additives (both RHA and BLA) are good pozzolans. Also, Table 1 shows the elemental oxides in the ordinary Portland cement used for this study. The constituents clearly show that the cement meet the stipulated standards as spelt out in the Nigerian Standards NIS 367 [33] and NIS 368-2 [34].

Table 2 shows that the liquid limit value for the soil sample is $62.8 \%$, while its plasticity index is $28.7 \%$, also, percentage passing through BS sieve No. 200 is $56 \%$ which is more than the stipulated $35 \%$, thus, making the soil a weak soil. On the basis of AASHTO 


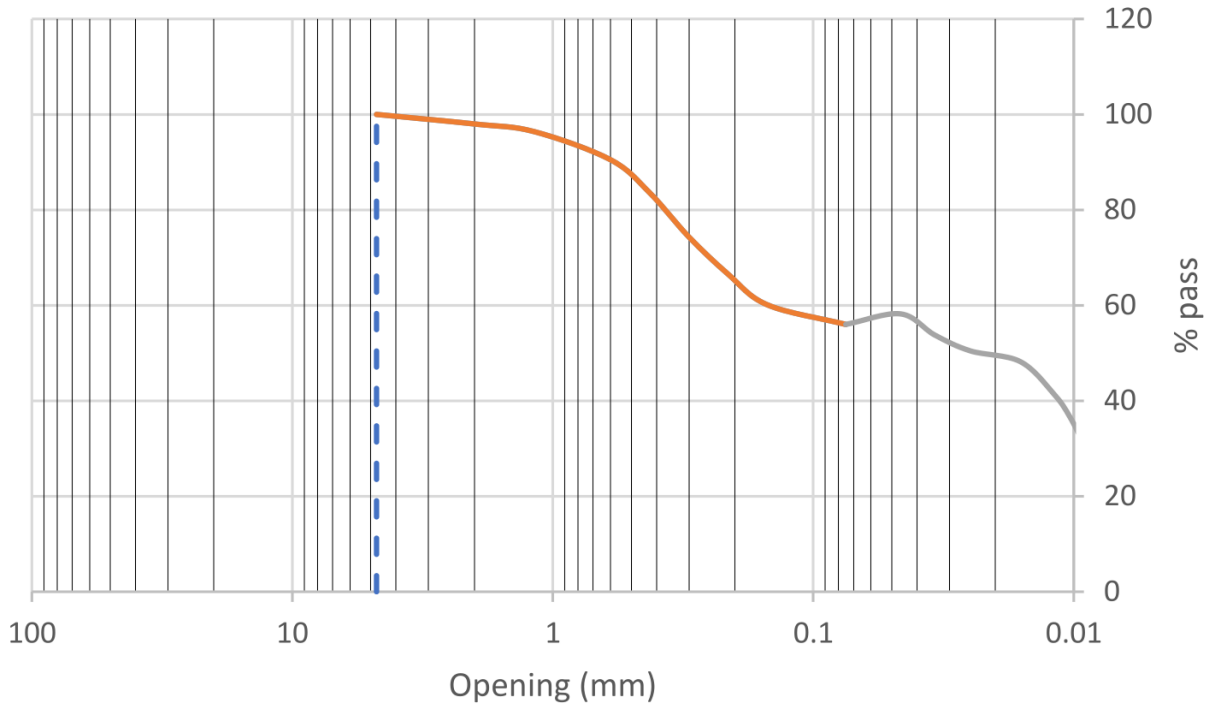

FiguRE 3. The particle size distribution and hydrometer curve of natural soil.

\begin{tabular}{lc}
\hline Properties & Results \\
\hline Natural Moisture Content (\%) & 10.42 \\
Liquid Limit (\%) & 62.8 \\
Plastic Limit (\%) & 34.1 \\
Plasticity Index (\%) & 28.7 \\
Specific gravity & 2.65 \\
Percentage passing No. 200 Sieve (\%) & 56 \\
AASHTO Classification & $\mathrm{A}-7-5$ \\
USCS Classification & $\mathrm{CH}$ \\
Maximum Dry Density (Kg/m ${ }^{3}$ ) & 1452 \\
Optimum Moisture Content (\%) & 15.2 \\
California Bearing Ratio (Soaked) (\%) & 4.0 \\
California Bearing Ratio (Unsoaked) (\%) & 7.4 \\
Colour & Reddish-Brown \\
\hline
\end{tabular}

TABLE 2. Summary preliminary results of natural soil sample.

classification, the soil sample is said to be in the A-7-5 subgroup, if the difference between the value of liquid limit and 30 is equal or greater than the value of the soil's plasticity index (plasticity index $\leq L L-30) ; 28.7 \leq 62.8-30=(32.8)$. The soil sample can therefore be said to fall into the A-7-5 subgroup, also, on the basis of Unified Soil Classification System (USCS), the A-7-5 soil sample is of high clay content $(\mathrm{CH})$, since soils with liquid limit values of more than $50 \%$ are of high clay content [35].

Figure 3 shows the particle size distribution and hydrometer test curve of the soil sample, $56 \%$ pass through BS sieve No. 200 as shown in Table 2 .

Figures 4 and 5 show the effects of cement + BLA and cement + RHA respectively on the A-7-5 soil sample. Generally, the values of liquid limits in both cases reduced, which is an indication of soil improvement 36 .

Figures 6] and 7] show the effects of cement + BLA and cement $+\mathrm{RHA}$ respectively on the A-7-5 soil sam-

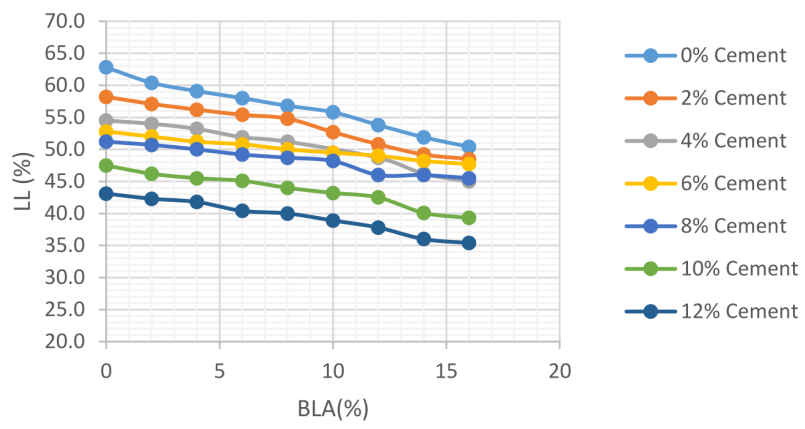

Figure 4. Graph of liquid limit (LL) against BLA + A-7-5 soil.

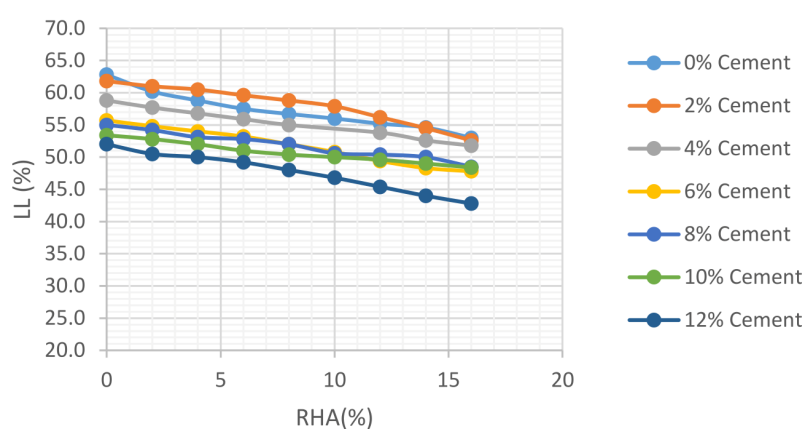

Figure 5. Graph of liquid limit (LL) against $\mathrm{RHA}+\mathrm{A}-7-5$ soil.

ple. Generally, the values of plastic limits in both cases reduced.

Figures 8 and 9 show the effects of cement + BLA and cement + RHA respectively on the A-7-5 soil sample. Generally, the values of plasticity index in both cases reduced, which is also an indication of soil improvement [36].

Figures 10 and 11 show the effects of cement + BLA and cement + RHA respectively on the maximum dry density property of the A-7-5 soil sample. 


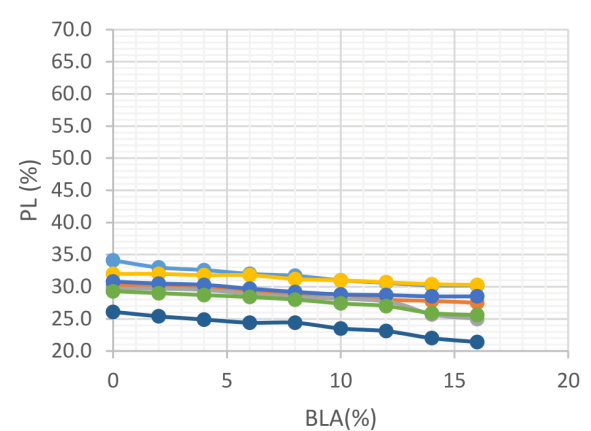

Figure 6. Graph of plastic limit (PL) against BLA + A-7-5 soil.
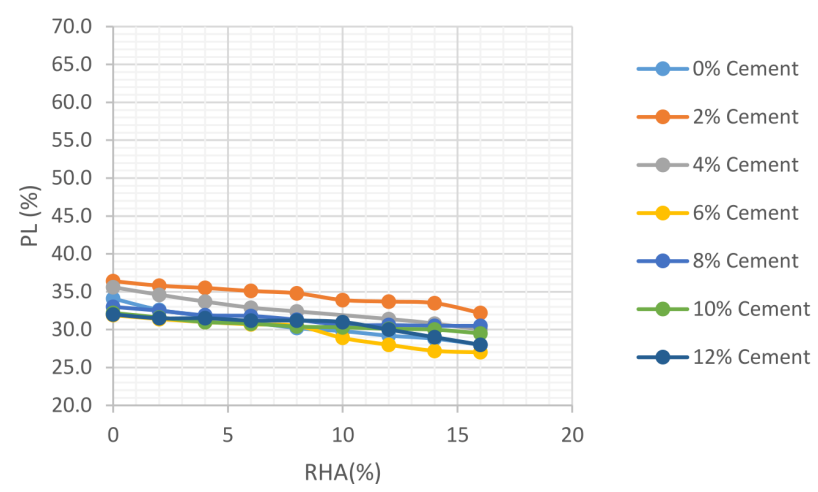

FiguRE 7. Graph of plastic limit (PL) against $\mathrm{RHA}+\mathrm{A}-7-5$ soil.
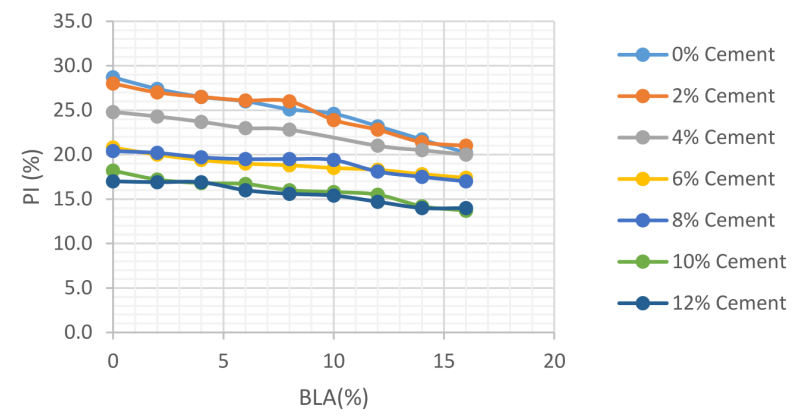

Figure 8. Graph of plasticity index (PI) against BLA + A-7-5 soil.

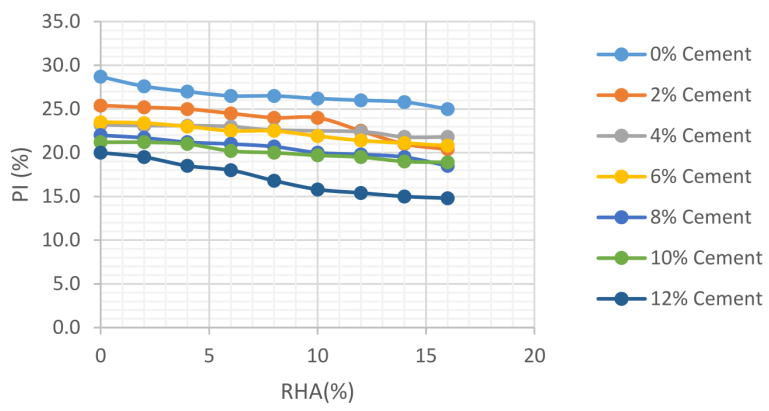

Figure 9. Graph of plasticity index (PI) against $\mathrm{RHA}+\mathrm{A}-7-5$ soil.

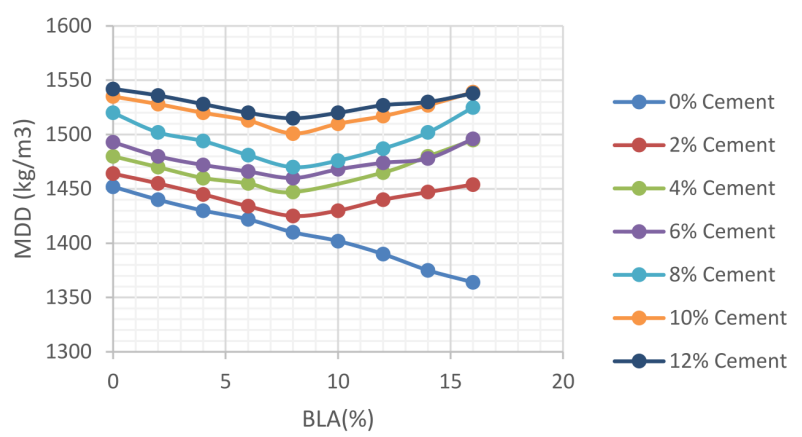

Figure 10. Graph of MDD against BLA for A-7-5 soil at varying amount of cement.

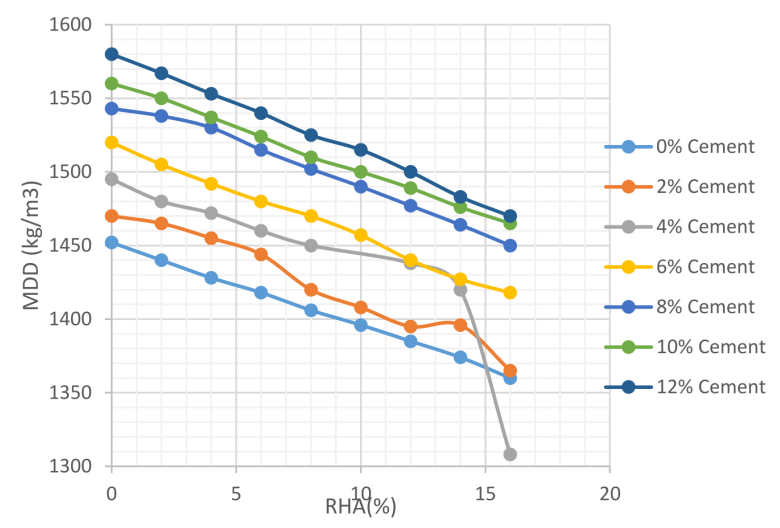

Figure 11. Graph of MDD against RHA for A-7-5 soil at varying amount of cement.

Figures 12 and 13 show the effects of cement + BLA and cement + RHA respectively on the optimum moisture content (OMC) of the property of the A-7-5 soil sample. Values of optimum moisture content increased at all levels of composition.

Figures 14, 15, 16 and 17 show the effects of cement + BLA and cement + RHA respectively on the California bearing ratio (both unsoaked and soaked) of the property of the A-7-5 soil sample. The general trend is that value increased, got to a peak and later decreased to a minimum value.

Figure 18 shows the comparison between results of CBR tests using admixtures, BLA and RHA on cement-treated A-7-5 soil at optimum values of $6 \%$ cement $+8 \%$ BLA and $8 \%$ cement $+8 \%$ RHA respectively. The unsoaked CBR values were $66.7 \%$ and $78.5 \%$ for BLA and RHA respectively and soaked CBR values were $54.8 \%$ and $63.8 \%$. In both cases, the stabilized soil samples can conveniently be used as subbase. $6 \%$ cement $+8 \%$ BLA yielded strength nine times better and fourteen times better in terms of unsoaked and soaked CBR. While $8 \%$ cement $+8 \%$ RHA yielded strength eleven times better and sixteen times better in terms of unsoaked and soaked CBR. Under these conditions, RHA yielded more effective results in strength increase. This result may be attributed to the presence of more amorphous silica in the rice husk ash than in the bamboo leaf ash. Furthermore, the strength of the stabilized samples increased 


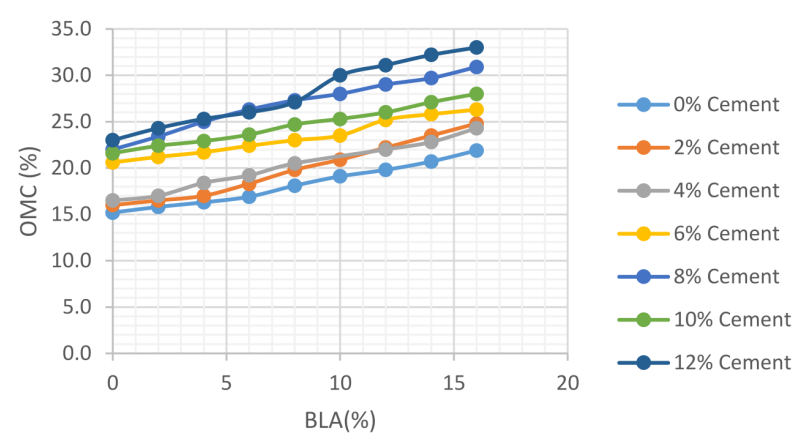

Figure 12. Graph of OMC against BLA for A-7-5 soil at varying amount of cement.

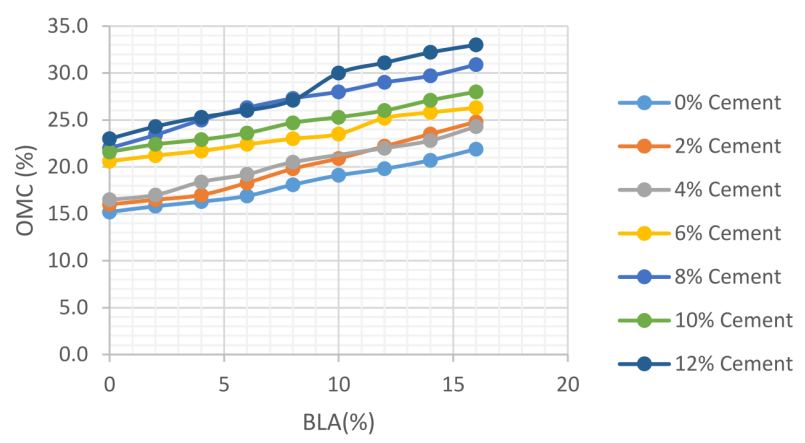

Figure 13. Graph of OMC against BLA for A-7-5 soil at varying amount of cement.

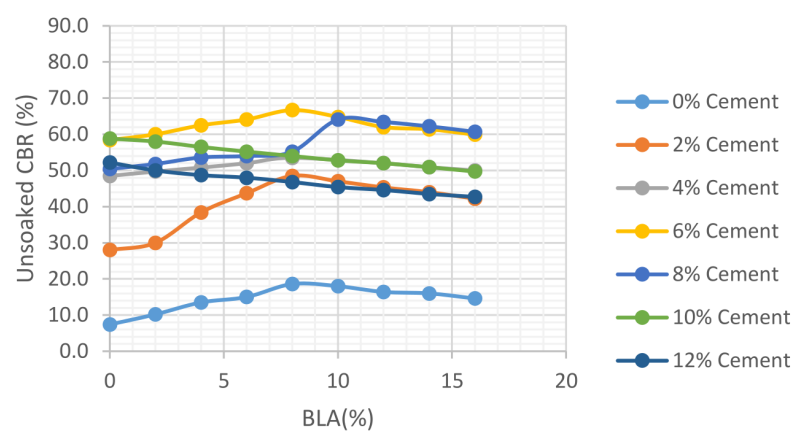

FiguRE 14. Graph of Unsoaked CBR against BLA for A-7-5 soil at varying amount of cement.

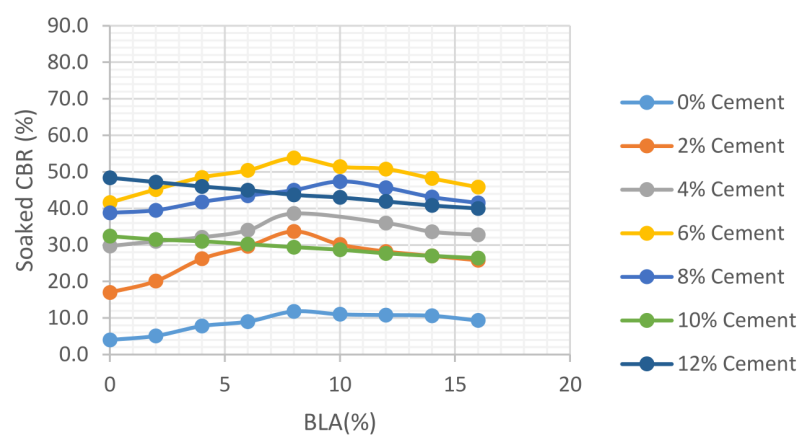

FiguRE 15. Graph of Soaked CBR against BLA for A-7-5 soil at varying amount of cement.

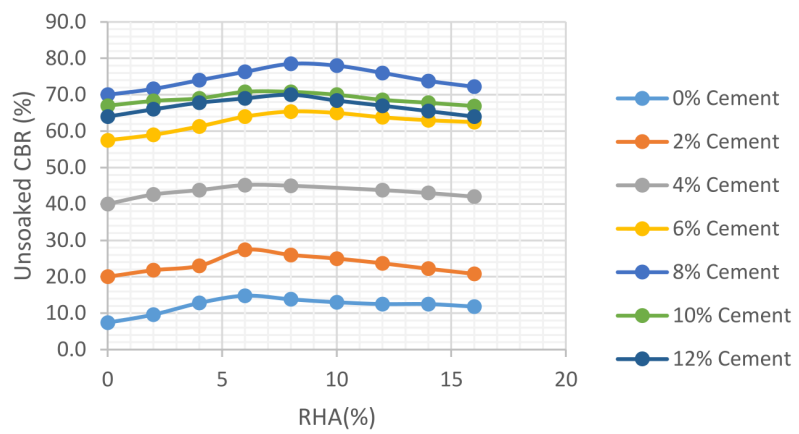

FiguRE 16. Graph of Unsoaked CBR against RHA for A-7-5 soil at varying amount of cement.

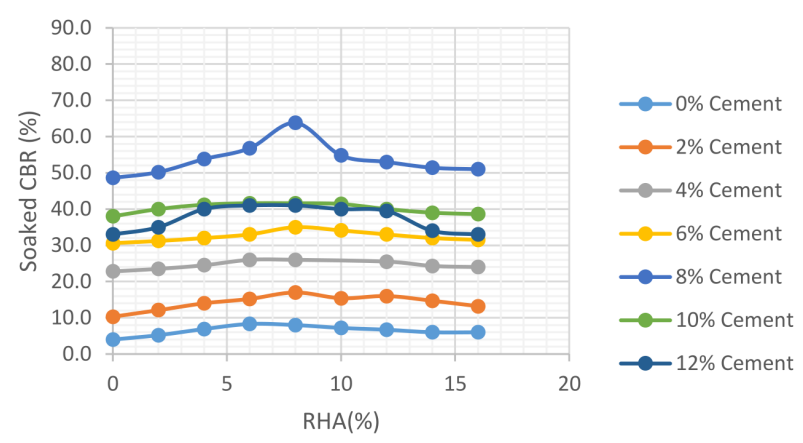

FiguRE 17. Graph of Soaked CBR against RHA for A-7-5 soil at varying amount of cement.

during the curing period as a result of continuing hydration/pozzolanic reactions [37].

\subsection{InVESTIGATION OF SOIL MiCROSTRUCTURE}

X-Ray Diffraction (XRD) and Scanning Electron Microscopy (SEM) techniques were employed to study the soil samples in terms of their microstructural changes relating to strength increase and identification of new compounds formed as a result of pozzolanic reaction.

\subsection{X-RAY DIFFRACTION}

A quantitative assessment of soil mineral composition was performed using PW 1800 (Rigaku D/Max-IIIC). XRD investigation was conducted at 7 curing days to evaluate the samples at natural A-7-5 soil, A-7-5 soil $+6 \%$ cement $+8 \%$ BLA mixing and also A-7-5 + $8 \%$ cement $+8 \%$ RHA.

Figure 19 shows the X-ray diffractogram of natural A-7-5 soil.

Mineral compounds identified in the tests can be categorized as clay minerals, non-clay minerals and additive and new reaction products. Diffraction patterns of the untreated A-7-5 soil sample are as shown in Figure 19. Kaolinite and quartz are of the major clay minerals found in the natural soil sample. This is an indication that they are formed under good drainage conditions 38. Others are vermiculite, illite and feldspar. The presence of vermiculite makes the soil slightly expansive in nature 39 . The structure of illite 


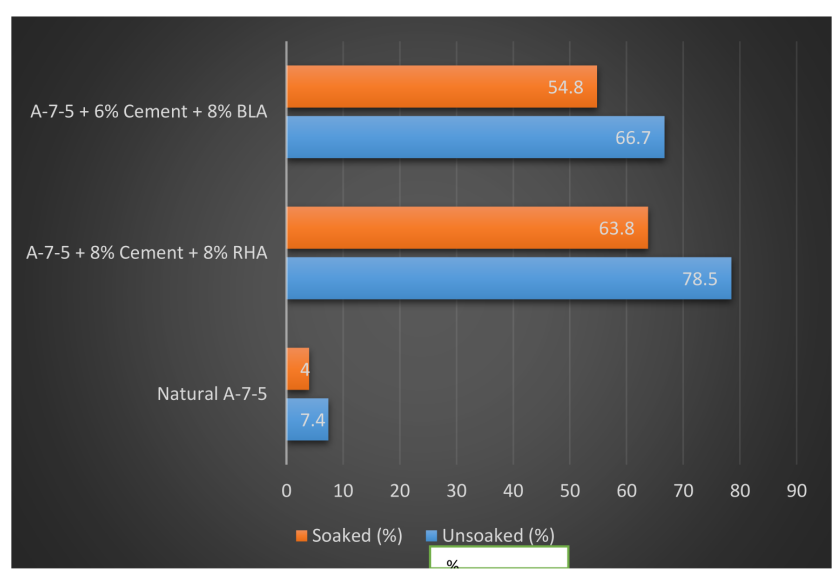

FigurE 18. Soaked and Unsoaked CBR comparison of BLA and RHA for cement-treated A-7-5 soil at optimum states.

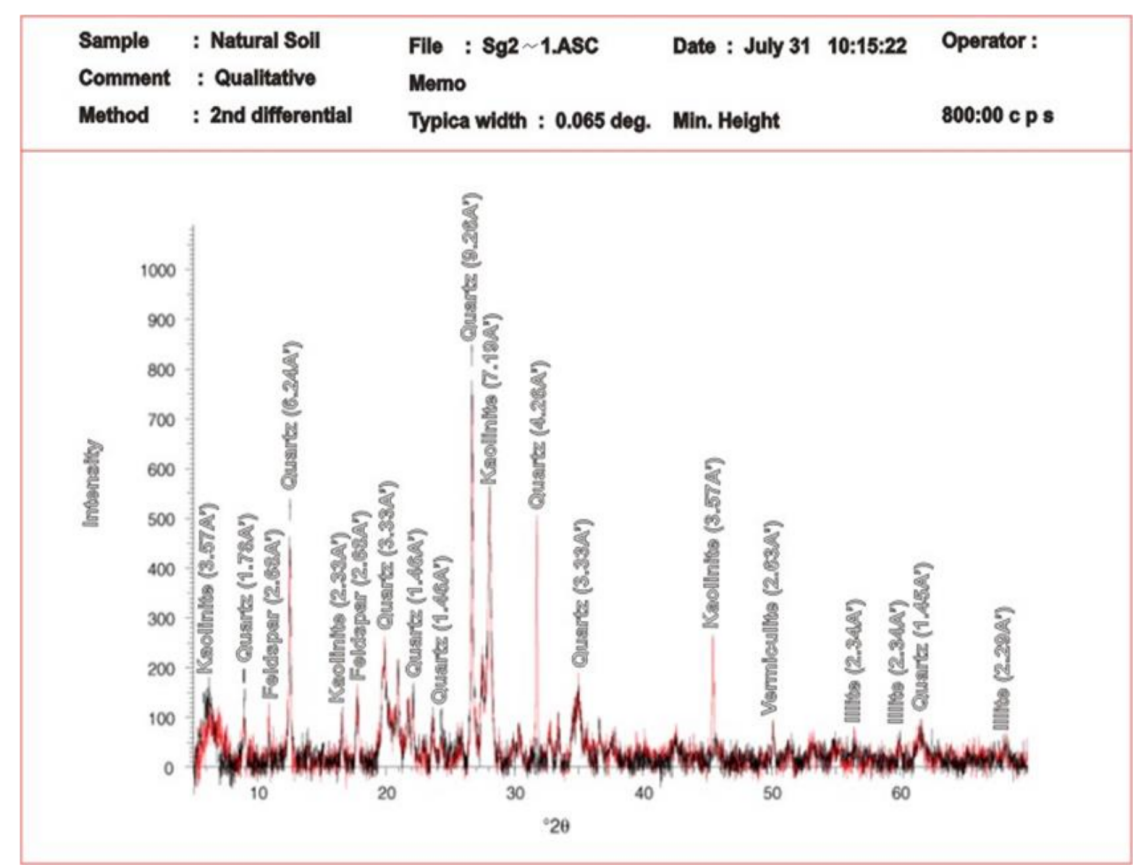

Figure 19. Soaked and Unsoaked CBR comparison of BLA and RHA for cement-treated A-7-5 soil at optimum states.

is the same as that of mica. One octahedral layer occurs between the two tetrahedral layers of silica, one at the top and the other at the bottom. The octahedral layer is joined with the tetrahedral layer when the top oxygen of the tetrahedral layer occupies the position of the hydroxyl of the octahedral layer. One-sixth of the silicon ions $\mathrm{Si}^{+++}$have been replaced from tetrahedral positions by aluminum ions, $\mathrm{Al}^{+++}$. Hence the potassium ions $\mathrm{K}^{+}$occur in the hexagonal cavity between the two units of illite and bind the illite units tightly. Illites as this, are non-expanding [39]. Feldspar consists of potassium (Potassium oxide), lime (Calcium oxide) and aluminum silicates of soda (Sodium oxide).

Figure 20 shows the X-ray diffractive image of cement-treated A-7-5 soil with bamboo leaf ash at optimum states $(6 \%$ cement $+8 \%$ BLA). Clay minerals like kaolinite and non-clay mineral like quartz are most prominent. The kaolinite group has little or no isomorphous substitution in other words the exchangeable cations would be very low. This, promotes good drainage and slightly acidic conditions that favor the formation of laterites containing relatively stable clay minerals such as kaolinite. Besides, the bonding is sufficiently strong that in the presence of water there is no absorption and thus no interlayer swelling [38]. Basically, the kaolinite subgroup clay minerals are known to be one of the least clay minerals in activity, thus, poses no threat [40]. XRD patterns of the cement-treated soils stabilized with the additives showed intensities that suggested the formation of new chemical compounds, generally, higher formation of desirable soil minerals-kaolinite and quartz, were formed. This reaction may be due to the hydration of cement that ultimately resulted to Calcium 


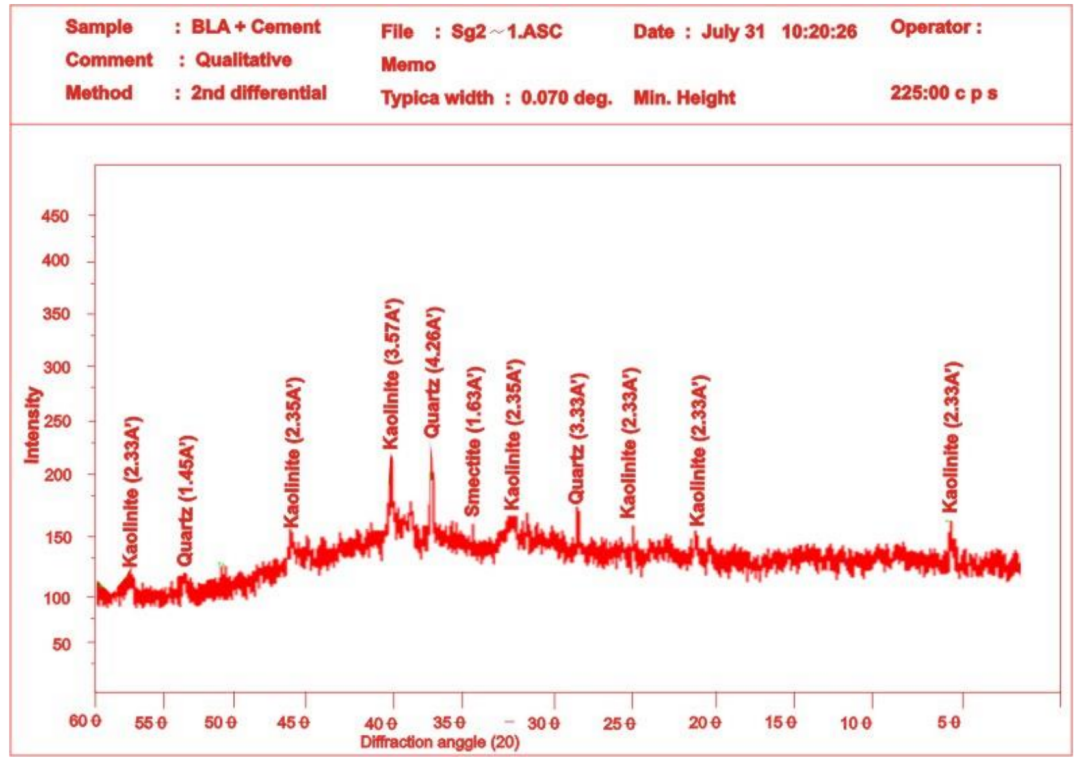

Figure 20. X-ray diffractogram of cement-treated A-7-5 soil stabilized with BLA at optimum state.

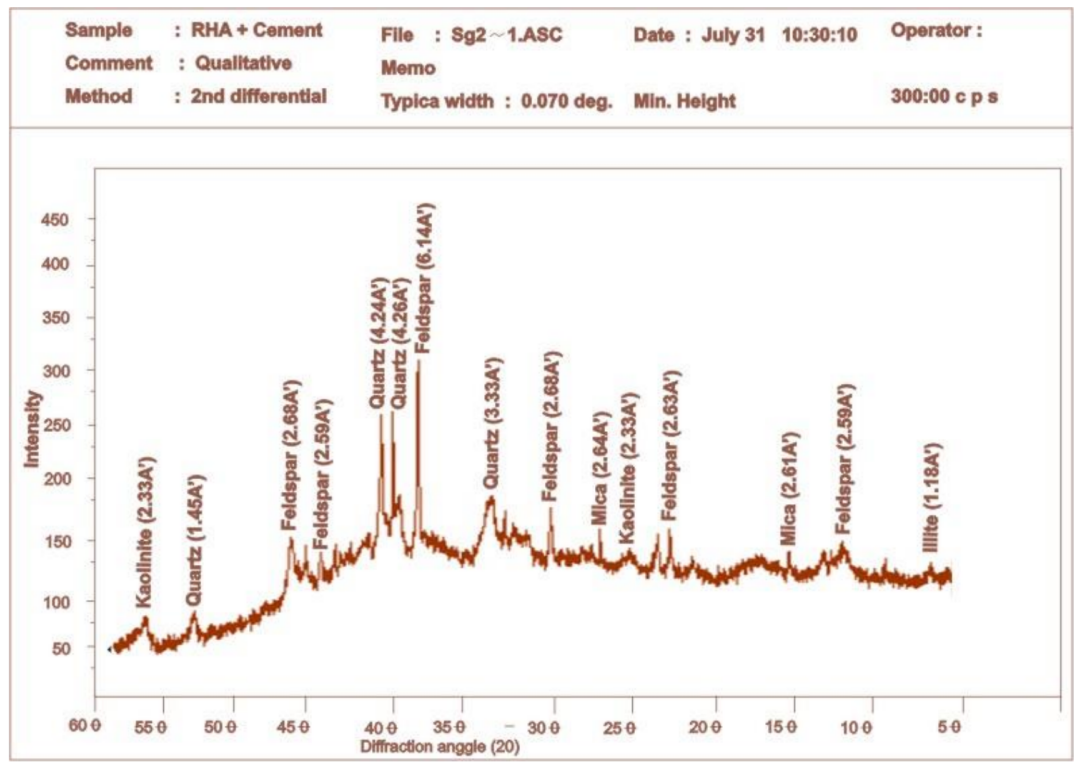

FigurE 21. X-ray diffractogram of cement-treated A-7-5 soil stabilized with RHA at optimum state.

silicate hydrate $(\mathrm{CSH})$ that contributed to strength development of the stabilized A-7-5 soil [1]. Feldspar, vermiculite and illite which were present in Figure 19 (natural A-7-5 soil) had disappeared in Figure 20 (A-75 stabilized with Cement and BLA). The domination of quartz and kaolinite in Figure 20 suggested that the swelling tendency of the natural A-7-5 had been considerably decreased. It can also be said that chemical reaction, which may be the cement hydration reaction has taken place.

Figure 21 shows the X-ray diffractive image of cement-treated A-7-5 soil with RHA at optimum states $(8 \%$ cement $+8 \%$ RHA). Feldspar got to a peak of $6.14 \mathrm{~A}^{0}$ from $2.68 \mathrm{~A}^{0}$ (at natural soil), the peak point of quartz in the natural soil state is seen to have disappeared in the stabilized state, mica has appeared, a confirmation that a physico-chemical reaction has taken place with the formation of new chemical compounds from pozzolanic reaction among soil, cement and the additive-RHA [41. Increase in Feldspar, a mineral rich in Calcium oxide, a major contributory compound of strength in cement, indicates enhancement of strength properties. Also, the appearance of mica suggests increase in strength value since mica is a rock forming material [42].

\subsection{SCANning ELECTron microscope (SEM)}

The microstructure of the samples before and after treatment was observed. The SEM provided micrographs that show up the bond formation, surface texture, mineral structure and geometry of the specimens 41. 


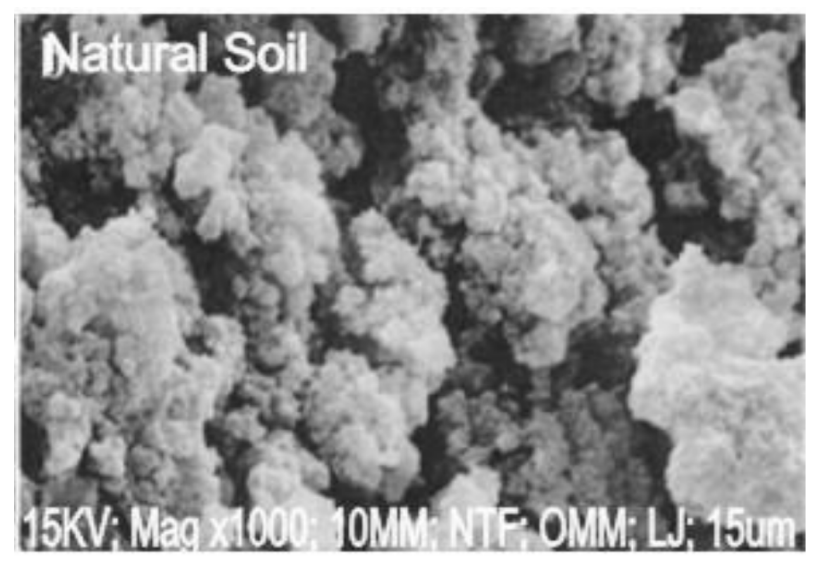

FIGURE 22. SEM micrograph of natural A-7-5 soil sample at $15 \mu \mathrm{m}$ and Mag X1000.

SEM images of the natural A-7-5 soil microstructure before treatment is shown in Figure 22 Figure 22 shows the micrograph of the natural soil micron thickness $(20 \mu \mathrm{m})$. The micrographs illustrate the flaky arrangement of the clay particles (kaolinite) as matrix between the detrital fine grains. The concentration and the distribution of the clay particles are not regular, some parts likely contain more clay particles and less detrital grains and others contain more detrital grains and less clay particles.

Figure 23 shows SEM micrograph of cement-treated A-7-5 soil stabilized with BLA at optimum state. The figure illustrates a micrograph of A-7-5 soil treated and stabilized with $6 \%$ cement $+8 \%$ BLA (optimum amount) and cured for 7 days. The micrograph shows crumbs of floccules with a porous nature and cementitious compounds (calcium aluminum hydrate and calcium silicate hydrate) coating the relics of the soil particles and the flocs. The edges of the relics of the A-7-5 soil particles and their boundaries have a raggedform. Furthermore, the reaction of BLA with cement treated A-7-5 soil led to the formation of aggregates of various sizes and this is responsible for the decrease in porosity of the soil system. Similar microfabric was observed by [43 46]. This can be attributed to the increase in the strength values (CBR) of the stabilized samples.

Figure 24 illustrates a micrograph of A-7-5 cementtreated soil stabilized with RHA, $8 \%$ cement $+8 \%$ RHA and was cured for 7 days. The micrograph shows aggregated arrangements due to flocculation and formation of hydration reaction products coating and cementing the soil- and the RHA-particles together. This microfabric is silt-fine sand like structure, suggesting that it is less plastic when compared to the natural soil state. This change in structure may be attributed to the higher values in terms of California Bearing Ratio (CBR).

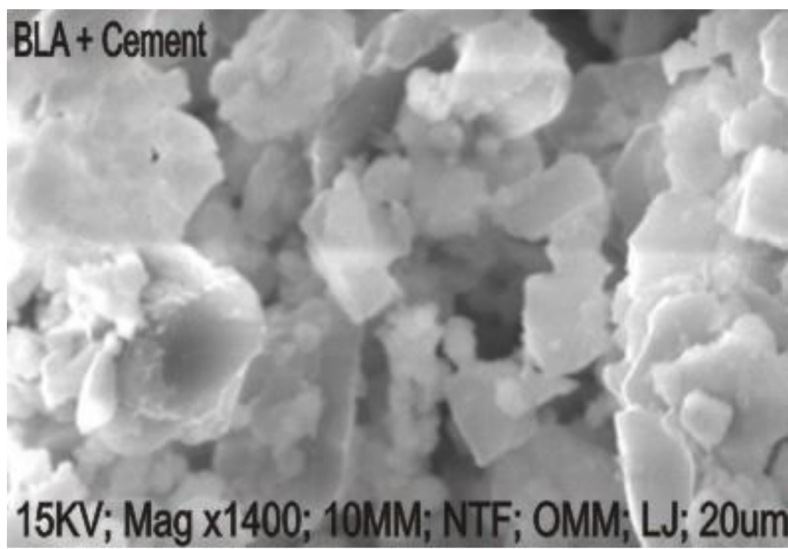

FigURE 23. SEM micrograph of cement-treated A-7-5 soil stabilized with BLA at optimum state.

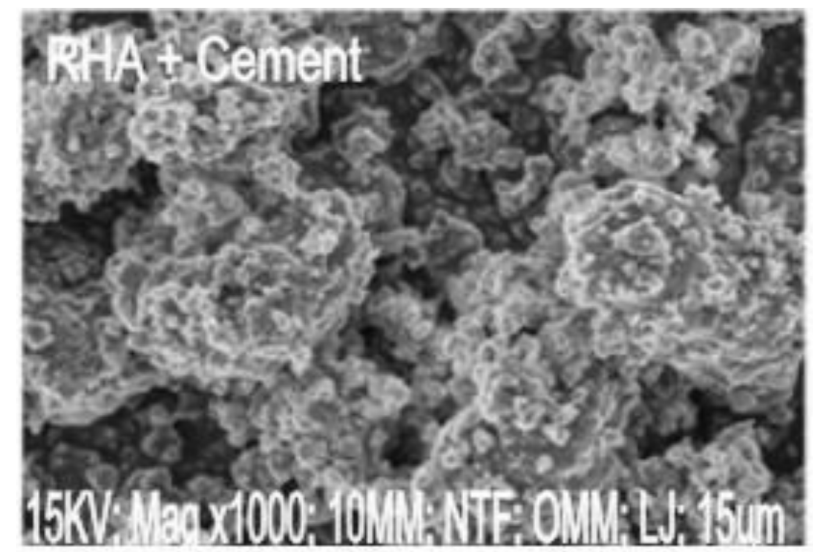

Figure 24. SEM micrograph of cement-treated A-7-5 soil stabilized with RHA at optimum state.

\section{Conclusions}

(1.) Based on the index properties, the soil sample was classified to be A-7-5 in the AASHTO rating and in the Unified Soil Classification System, the soil sample was $\mathrm{CH}$ respectively, also, on the basis of the chemical composition of the soil, the soil sample was classified as laterite. Chemical compositions of BLA and RHA showed that they were pozzolans;

(2.) The addition of both the cement + BLA and cement + RHA improved the CBR of the soil. From $7.4 \%$ and $4 \%$ (unsoaked and soaked CBR) at natural states to $66.7 \%$ and $54.8 \%$ (unsoaked and soaked CBR) for cement + BLA, $78.5 \%$ and $63.8 \%$ (unsoaked and soaked CBR) for cement + RHA. Thereby making an initially weak soil suitable for use as subbase;

(3.) There are optimum amounts (BLA, RHA and Cement) of additives for effectively stabilizing the soil sample, which are $6 \%$ cement $+8 \%$ BLA and $8 \%$ cement $+8 \%$ RHA;

(4.) The scanning electron miscroscopy (SEM) and $\mathrm{X}$-ray diffraction (XRD) tests clearly showed that pozzolanic and cement hydration reactions actually took place in the course of stabilization. 


\section{REFERENCES}

[1] A. A. Bello, J. A. Ige, H. Ayodele. Stabilization of lateritic soil with cassava peel ash. British Journal of Applied Science and Technology 7(6):642-650, 2015. https://doi.org/10.9734/BJAST/2015/16120.

[2] M. A. Joel. A review of partial replacement of cement with some agro wastes. Nigerian Journal of Technology 29(2):12-20, 2010.

[3] S. Y. Wang, S. Kenichi, J. T. DeJong, A. J. Kabla. Microscale visualization of microbial-induced calcium carbonate precipitation processes. Journal of Geotechnical and Geoenvironmental Engineering 145(9), 2019. https:

//doi.org/10.1061/(ASCE)GT.1943-5606.0002079

[4] M. G. Gomez, J. T. DeJong. Engineering properties of bio-cementation improved sandy soils. In Grouting 2017, pp. 23-33. 2017. https://doi.org/10.1061/9780784480793.003.

[5] J. T. Dejong, M. G. Gomez, J. T. Waller, G. Viggiani. Influence of bio-cementation on the shearing behavior of sand using X-ray computed tomography. In Geotechnical Frontiers 2017, pp. 871-880. 2017. https://doi.org/10.1061/9780784480472.093

[6] E. Vitale, G. Russo, D. Deneele. Use of alkali-activated fly ashes for soil treatment. In Geotechnical Research for Land Protection and Development, pp. 723-733. 2020. https://doi.org/10.1007/978-3-030-21359-6_77.

[7] E. Vitale, G. Russo, D. Deneele. Multi-scale analysis on soil improved by alkali activated binders. In E3S Web of Conferences. $7^{\text {th }}$ International Symposium on Deformation Characteristics of Geomaterials, p. 11003. 2019.

https://doi.org/10.1051/e3sconf/20199211003

[8] O. O. Amu, S. A. Ogunniyi, O. O. Oladeji. Geotechnical properties of lateritic soil stabilized with sugarcane straw ash. American Journal of Scientific and Industrial Research 2(2):323-331, 2011. https://doi.org/10.5251/ajsir.2011.2.2.323.331

[9] O. O. Amu, S. S. Babajide. Effects of bamboo leaf ash on lime stabilized lateritic soil highway constructions. Research Journal of Applied Sciences, Engineering and Technology 3(4):278-283, 2011.

[10] S. Adhikary, K. Jona. Potentials for rice husk ash as a soil stabilizer. International Journal of Latest Research in Engineering and Technology 2(2):40-48, 2016.

[11] M. Alhassan. Potential of rice husk ash for stabiization. AU J T 11(4):246-250, 2008.

[12] D. Shrivastava, A. K. Singhai, R. K. Yadav. Effect of lime and rice husk ash on engineering properties of black cotton soil. International Journal of Engineering Research and Science and Technology 3(2), 2014.

[13] E. Villar-Cocina, E. V. Morales, S. E. Santos, et al. Pozzolanic behavior of bamboo leaf ash. Characterization and determination of the kinetic parameters. Cement and Concrete Composites 33(1):68-73, 2011. https: //doi.org/10.1016/j.cemconcomp.2010.09.003

[14] Z. A. Rahman, H. H. Ashani, A. R. Sahibin, et al. Effect of rice husk ash addition on geotechnical characteristics of treated residual soil. AmericanEurasian journal of agricultural \& environmental sciences 14(12):1368-1377, 2014. https://doi.org/10 5829/idosi.aejaes.2014.14.12.12462.
[15] C. Prakash, M. S. Nagakumar. Studies on soil stabilization by using bagasse ash. International Journal of Latest Research in Engineering and Technology pp. 89-94, 2014.

[16] T. H. T. Ogunribido. Potentials of sugar cane straw ash for lateritic soil stabilization in road construction. International Journal of Science \& Emerging Technologies 3(5), 2011.

[17] Y. A. Jimoh, O. A. Apampa. An evaluation of the influence of corn cob ash on the strength parameters of lateritic soils. Civil and Environmental Research 6(5):1-10, 2014.

[18] E. S. Nnochiri, H. O. Emeka, M. O. Daramola. Assessment of the effects of guinea corn husk ash on lime stabilized lateritic soil. Journal of Engineering and Technology 9(1):1-13, 2018.

[19] A. E. Adetoro, J. O. Adam. Comparative analysis of Ekiti state soil stabilized with different additives. Asian Journal of Science and Technology 6(12):2054-2058, 2015.

[20] E. Nnochiri, O. O. Aderinlewo. Geotechnical properties of lateritic soil stabilized with ashes of oil palm fronds. The Civil Engineering Journal 4:22, 2016. https://doi.org/10.14311/CEJ.2016.04.0022.

[21] B. Krishanu, V. Janani. Effects of strength characteristics on lateritic soil using lime and sugarcane baggase ash. In International Conference on Engineering Innovations and Solutions (ICEIS), pp. 90-94. 2016.

[22] M. Ahmad. Rice production in Nigeria hits 15 million tonnes. Premium Times Newspaper, 2017.

[23] D. Dermatas, X. Meng. Utilization of fly ash for stabilization/solidification of heavy metal contaminated soils. Engineering Geology 70(3-4):377-394, 2003. https://doi.org/10.1016/S0013-7952(03)00105-4.

[24] Z. Nalbantoglu. Effectiveness of Class C fly ash as an expansive soil stabilizer. Construction and Building Materials 18(6):377-381, 2004. https : //doi.org/10.1016/j.conbuildmat.2004.03.011

[25] J. B. Adeyeri, A. Bolarinwa, C. O. Toochukwu. Geotechnical properties of soils in Ikole Ekiti area, Southwestern Nigeria. Electronic Journal of Geotechnical Engineering 22(1):21-32, 2017.

[26] H. B. Kehinde, S. A. Hull. Using a domain model of social tenure to record land rights: A case study of Itaji-Ekiti, Ekiti State, Nigeria. South African Journal of Geomatics 8(2):217-220, 2019. https://doi.org/10.4314/sajg.v8i2.8

[27] British Standards Institute. BS 12, Specifications of portland cement. London, 1991.

[28] Federal Ministry of Works and Housing. Nigerian general specifications for roads and bridges. Vol. 11, Federal Highway Department, FMWH: Lagos, Nigeria, 1997.

[29] British Standards Institute. BS 1377, Methods of testing soils for civil engineering purposes. London, 1990.

[30] British Standards Institute. BS 1924, Methods of test for stabilized soils. London, 1990. 
[31] S. A. Ola. Geotechnical properties and behavior of some Nigerian lateritic soil. In Tropical Soils of Nigeria in Engineering Practice, pp. 61-84. 1983.

[32] American Society for Testing and Materials (ASTM). ASTM C618, Standard specification for coal flyash and raw or calcined natural pozzolan for use in concrete. West Conshohocken, 2003.

[33] NIS-367. Standard test methods for the characteristics of cement (Part 1 - Test for physical properties). Nigerian Industrial Standards (NIS), 1997.

[34] NIS-368-2. Standard test methods for the characteristics of cement (Part 2 - Test for chemical properties). Nigerian Industrial Standards (NIS), 1997.

[35] N. J. Garber, L. A. Hoel. Traffic and Highway Engineering. Fourth Edition. ENGAGE Learning, 2009.

[36] M. Y. Fattah, F. H. Rahil, K. Y. H. Al-Soudany. Improvement of clayey soil characteristics using rice husk ash. Journal of Civil Engineering and Urbanism 3(1):12-18, 2013.

[37] A. A. Amadi, A. S. Osu. Effect of curing time on strength development in black cotton soil-quarry fines composite stabilized with cement kiln dust (CRD). Journal of King Saud University - Engineering Sciences 30(4):305-312, 2018.

https://doi.org/10.1016/j.jksues.2016.04.001.

[38] O. O. Ige, O. Ogunsanwo, K. A. Aweda. Geotechnical and mineralogical evaluation of some lateritic soils from southwestern nigeria. Electronic Journal of geotechnical Engineering 19:301-312, 2014.
[39] Soil management - soil properties. [2019-04-16], https :

//www.soilmanagementindia.com/soil-properties

[40] U. N. Okonkwo. Optimization of baggase ash content in cement. Doctoral thesis, University of Nigeria, Nsukka, 2015.

[41] S. Jaritngam, O. Somchaimeek, P. Taneeranon. Feasibility of lateritic-cement mixture as pavement base course aggregate. Iranian Journal of Science and Technology - Transactions of Civil Engineering 38(11):275-284, 2014.

[42] clay mineral. [2019-04-16], https : //www.britannica.com/science/clay-mineral

[43] J. L. Eades, R. E. Grim. Behavior characteristics of lime-soil mixtures, chap. A quick test to determine lime requirements for lime stabilization, pp. 61-72. Highway Research Board, Washington, DC, 1966.

[44] J. B. Croft. The processes involved in the lime stabilization of clay soils. In Proceedings Australian Road Research Board, part 2, pp. 1169-1203. 1964.

[45] R. S. Narasimha, G. Rajasekaran. Behaviour of lime piles in a soft marine clay. In International Conference on Deep Foundations. Practice incorporating pile Talk, pp. 185-192. 1992.

[46] G. Rajasekaran, S. N. Rao. Particle size analysis of lime-treated marine clays. Geotechnical Testing Journal 21(2):109-119, 1998.

https://doi.org/10.1520/GTJ10749J 